Editorial

\title{
Introduction: How Different Were the European Elections of 2014?
}

\author{
Wouter van der Brug ${ }^{1}$, Katjana Gattermann ${ }^{2,3}$ and Claes H. de Vreese ${ }^{2}$ \\ ${ }^{1}$ Department of Political Science, University of Amsterdam, 1018 WV Amsterdam, The Netherlands; \\ E-Mail: W.vanderBrug@uva.nl \\ ${ }^{2}$ Amsterdam School of Communication Research, University of Amsterdam, 1018 WV Amsterdam, The Netherlands; \\ E-Mails: k.gattermann@uva.nl (K.G.), C.H.deVreese@uva.nl (C.H.V.) \\ ${ }^{3}$ Amsterdam Centre for Contemporary European Studies, University of Amsterdam, 1018 WV Amsterdam, \\ The Netherlands
}

Submitted: 8 February 2016 | Published: 29 February 2016

\begin{abstract}
This issue brings together papers that focus on the question of whether and in which ways the 2014 European Parliament elections were different from previous ones. This is important from the point of view of emerging scholarship on changes in the EU and from the point of view of the self-proclaimed 'This time it's different!' slogan from the Parliament. The papers centre around three themes: 1) the role of the Spitzenkandidaten, 2) media and voters, and 3) electoral behaviour.
\end{abstract}

\section{Keywords}

campaigns; elections; European Parliament; media coverage; media effects; parties; Spitzenkandidaten; voting behaviour

Issue

This editorial is part of the issue "How Different Were the European Elections of 2014?", edited by Wouter van der Brug, Katjana Gattermann and Claes de Vreese (University of Amsterdam, The Netherlands).

(C) 2016 by the authors; licensee Cogitatio (Lisbon, Portugal). This article is licensed under a Creative Commons Attribution 4.0 International License (CC BY).

\section{Introduction}

European Parliament elections are in several ways different from national elections (e.g., Reif \& Schmitt, 1980; Schmitt \& Thomassen, 1999; Thomassen, 2009; Van der Brug \& de Vreese, 2016; Van der Eijk \& Franklin, 1996; Van der Brug \& Van der Eijk, 2007). For one thing, national elections do, to some extent, provide voters with the opportunity to hold incumbents accountable for their past actions and provide representatives with an electoral mandate to take decisions on their behalf. Yet, the complex multi-level governance of the EU makes it less likely that European Parliament (EP) elections can function in the same way as national elections. Up until 2014 there was no connection between the outcome of EP elections and the composition of the prime executive agent at the EUlevel, the European Commission. Moreover, some of the most important EU decisions are ultimately taken by a majority vote of the heads of state in the European Council, who are in turn accountable to the national parliaments.

Thus, up until recently, EP elections did not enable voters to hold politicians directly accountable for EU policies. In addition, parties hardly ever discuss the contents of European policies during the campaigns, thus making it difficult for voters to give an electoral mandate for those policies. Previous research on European elections has demonstrated that voters, faced with elections that do not serve a clear purpose (e.g., Franklin, 2014), treat these as second-order national elections (Reif \& Schmitt, 1980). According to this view, voters either use these elections to express loyalty to a national party, or they use them as a referendum on the performance of the national government. When dissatisfied with the current national government they are more likely to cast a protest vote than they would at national elections (e.g., Van der Eijk, Franklin, \& 
Marsh, 1996). Even though the second-order election thesis has been challenged (e.g., Hobolt \& Spoon, 2012; Hobolt, Spoon, \& Tilley, 2009), it is still a dominant perspective on European elections. However, there are three reasons why one could expect the 2014 EP elections to be different.

Firstly, the 2014 EP elections were the first in which frontrunner candidates of the five largest European political party families were put forth as the candidates for chairing the European Commission after the elections (the so called Spitzenkandidaten). This was done explicitly in order to show to the voters that executive power would also be at stake this time. The Spitzenkandidaten participated in several debates catering-at least in theory-to a pan-European audience. In this way, the prime executive figure in the Commission could claim to have an electoral mandate and this would ideally render the outcome of the elections more important. The EP campaign slogan 'This time it's different!' made it clear that the EP sought to make voters aware of its new powers, which it claimed on the basis of the Lisbon Treaty.

Secondly, the 2014 EP elections were held in the midst of a severe financial and economic crisis, which changed the nature of European collaboration as the EU had launched major rescue packages, introduced oversight mechanisms, and established a European semester system in the budget mechanism of member states. At the same time, EU citizens stridently protested against tight austerity measures across Europe, for which many people in the Southern countries held the EU (at least partially) responsible. Moreover, a growing number of EU citizens has been opposing further EU integration, such as the Euro rescue funds, a common immigration policy, or extensions to the freedom of movement. Even if this did not impinge directly upon the nature of European elections per se, one could expect these events to increase the interest of media and voters in European politics in general.

Thirdly, the 2014 EP elections were held during a period when Eurosceptic parties at the left and right end of the political spectrum were doing very well in the polls. Many of these parties campaigned with Eurosceptic messages and the anticipated success of these parties was therefore considerable. At the very least, one might expect there to be increased politicization about the European project.

Even though there are thus some reasons to expect the 2014 EP elections to be less second-order than previous ones, we do not know whether this was indeed the case. If voters were unaware of the Spitzenkandidaten, this new arrangement will not have had much effect. Some voters may have been dissatisfied with the austerity measures the 'troika' imposed on Southern European member states, but even in the current setup of the EU there are few possibilities for them to use EP elections to hold anyone accountable for those policies. This issue brings together papers that focus on the question of whether and in which ways the 2014 EP elections were different from previous ones. ${ }^{1}$ This is important from the point of view of emerging scholarship on changes in the EU and from the point of view of the self-proclaimed 'This time it's different!' slogan from the Parliament. The papers centre around three themes: 1) the role of the Spitzenkandidaten, 2) media and voters, and 3) voting behaviour. We will briefly discuss each of these.

\section{Theme 1: New Features of the Elections: The Role of the Spitzenkandidaten}

The first theme concerns the key new feature of the 2014 EP elections, namely the role of the Spitzenkandidaten. The underlying question of those papers in this issue that focus on their role is whether and how the personalisation of the campaigns and the fact that executive power was at stake (to some extent) changed the nature of the EP elections. Prominent theories on the EU's democratic deficit would have expected this to be the case: Føllesdal and Hix (2006) as well as Hix (2008) have long suggested that open and rival candidacies for Commission President would, among other things, enhance electoral contestation; and electoral contestation would in itself 'allow a greater connection between voters' preferences and coalitions and alignments in the EU institutions' (Føllesdal \& Hix, 2006, p. 553). Enhancing electoral contestation would thus contribute to overcoming the EU's democratic deficit. Moreover, such a contest could also provide citizens with the necessary information to hold EU representatives accountable in EP elections and therewith alleviate the EU's accountability deficit (Hobolt \& Tilley, 2014). Elections in which candidates are up for reelection provide the most obvious possibilities to hold politicians accountable for their actions in the past. Since none of the Spitzenkandidaten had been an EU Commissioner in the past, it is unlikely that the accountability deficit could have been resolved in the 2014 EP elections. Yet, the fact that the Spitzenkandidaten were candidates for an important executive position, can be

\footnotetext{
${ }^{1}$ The plan for this issue originated at a workshop entitled 'The European Elections of 2014', which took place in Amsterdam on March 12 and 13, 2015. It was organised and funded by the Amsterdam Centre for Contemporary European Studies (ACCESS EUROPE), a centre jointly organised by the University of Amsterdam and the Free University Amsterdam. The issue brings together papers that were presented at this workshop, as well as papers that came in as a response to an open call. All papers were peer reviewed. We thank all authors, reviewers, the editors of Politics and Governance and the participants of the ACCESS EUROPE workshop for their collaboration and substantive input. The order of authors is alphabetical and reflects our equal contribution, both to this introduction as well as to the editorship of this special issue.
} 
expected to strengthen the electoral connection of voters and the European Commission.

This resonates with the motives of the European Parliament to foster the campaign context during the 2014 elections. In its resolution of November 22, 2012 it 'urge[d] the European political parties to nominate candidates for the Presidency of the Commission'. ${ }^{2}$ With this procedure, the EP had the intention to increase its own legitimacy as a parliament 'by connecting their respective elections more directly to the choice of the voters'. Moreover, the candidates were expected to 'play a leading role in the parliamentary electoral campaign, in particular by personally presenting their programme in all Member States of the Union', which implies that the EP expected the campaigns to raise the awareness and interest of European voters.

Against this backdrop, studying the role of Spitzenkandidaten becomes particularly important because it was the first time in the history of EP elections that the major European party families nominated top candidates for Commission President. For that reason, the consequences of the Spitzenkandidaten nomination were not yet known during the campaigns. The Lisbon Treaty gave the European Council the right to put forward their preferred candidate by prescribing that, '[t]aking into account the elections to the European Parliament and after having held the appropriate consultations, the European Council, acting by a qualified majority, shall propose to the European Parliament a candidate for President of the Commission' (Art. 17.7 TEU). Although the treaty only manifested the EP's right to elect the Presidential candidate-which it had de facto exerted since 1994 by its own interpretations of the Maastricht Treaty (see Hix, 2002)-the Parliament interpreted the new provisions as allowing it to nominate its own candidate, namely the Spitzenkandidat of the largest political party family. Remarkably, the heads of state in the European Council hardly commented on this procedure; and it was not clear during the campaigns whether they would even accept the Parliament's initiative (see also Hobolt, 2014). It was only on June 27,2014 , i.e., one month after the elections, that the Council 'agreed to propose Jean-Claude Juncker to the European Parliament as candidate for President of the European Commission' ${ }^{3}$. This uncertain yet politicised electoral context provided an exciting opportunity for scholars to study the nomination process, public perceptions of the Spitzenkandidaten as well as the electoral consequences of their campaigns.

The first contribution to this issue in this respect sheds light onto the candidate selection procedures

\footnotetext{
2 European Parliament resolution of November 22, 2012 on the elections to the European Parliament in 2014 (2012/2829 (RSP)).

${ }^{3}$ Conclusions of the European Council, June 26/27, 2014 (EUCO 79/14)
}

within the five European party families that put forward Spitzenkandidaten for the election campaigns. By relying on party documents and semi-structured interviews with relevant stakeholders, Put, Van Hecke, Cunningham and Wolfs (2016) argue that the novelty of the phenomenon also presented new opportunities and challenges for the European party families. The fact that the Spitzenkandidaten procedure was unprecedented and its outcome uncertain would explain why the Europarties largely relied on existing and more general intra-party decision-making procedures in the absence of specific rules. The various Europarties thus exhibited varying degrees of candidacy requirements, decentralisation, inclusion of the selectorate, and voting procedures. Yet Put et al. (2016) argue that the Europarties made use of the new tool to strengthen their own position at the EU level and expect that selection procedures will be further professionalised in the future.

While much of these internal selection procedures might have gone unnoticed by the public, the European media are crucial for informing European citizens about what is at stake in EU elections. This is why Schulze (2016) investigates the extent to which the Spitzenkandidaten were visible in major British, French, and German newspapers during the campaigns. She conducts a quantitative content analysis of the 2014 EP election campaign coverage in several broadsheets and tabloids. In order to comprehend how the Spitzenkandidaten were reported on across countries and newspapers, Schulze (2016) positions her findings within a broader analysis of EU election news. She finds that the Spitzenkandidaten were most visible in the German press, followed by the French press, while British newspapers hardly paid attention to the Spitzenkandidaten. Generally, broadsheets reported on them more often than tabloids. However, she argues that the Spitzenkandidaten did not contribute substantially to a personalization of news coverage during the three weeks before the 2014 EP elections, although the extent to which this happened differs across countries.

Ultimately, information is essential for the extent to which citizens can make sense of the Spitzenkandidaten: Gattermann, de Vreese, and van der Brug (2016) investigate the preference formation of Dutch citizens towards the three main contenders Juncker, Schulz, and Verhofstadt. They argue that regular news exposure and especially general information about the EU as well as campaign-specific information about the Spitzenkandidaten represent important pre-conditions for citizens to formulate a preference towards the candidates. Consequently, only few citizens actually provided their opinion; and only the most knowledgeable used cues of party identifications or ideological orientations in their evaluations of the Spitzenkandidaten. The authors argue that this might be due to the novelty of the procedure and warn that it should not be dismissed right away. Instead, they propose to increase 
the extent and salience of the campaign activities during the next EU elections in order to make EU citizens more aware and therewith to contribute to alleviating the EU democratic and accountability deficits.

Finally, Maier, Rittberger and Faas (2016) assess one particular novelty of the Spitzenkandidaten procedure: the so-called Eurovision debate, the major panEuropean televised debate in which five of the six candidates who were nominated by the major party families participated. The authors were interested in the effects of this debate on attitudes towards the EU and conducted a quasi-experiment with German students. Their results show that viewers of the debate generally became more favourable towards European integration and less frightened about the EU. Moreover, they find that respondents tended to provide positive feedback to the candidates' statements and that these positive evaluations also led to a shift towards more proEuropean attitudes. Prior political knowledge, however, played no major role in the perceptions and evaluations of the debates. But this does not imply that the debates are not important for attitude formation and ultimately political behaviour. On the contrary, the authors recommend making such debates between the Spitzenkandidaten more attractive for voters across Europe in future EU election campaigns.

\section{Theme 2: The Media and Voters}

Looking at the second theme, 'the media and voters', the contributions to this issue analyse mediated party mobilisation efforts and media effects on EU attitudes and electoral behaviour. Traditionally, the literature on the media and voters has taken as a starting point the idea of the EU being a 'distant polity' removed from most people's daily lives. A sizeable body of literature, using both experiments, media content data, and (panel) survey data, has provided ample evidence for significant effects of media on citizens' attitudes towards the EU and their voting behaviour (see de Vreese \& Boomgaarden, 2016, for a recent overview). In more recent years, a shift can be noted in the research towards specifying the conditions under which media and information has an effect on public attitudes and electoral behaviour.

Using experimental evidence, exposure to framing EU enlargement news in positive and beneficial terms (versus negative and threatening terms) affects participants' support for the EU's future enlargement (De Vreese \& Boomgaarden, 2003; De Vreese, Boomgaarden, \& Semetko, 2011; Maier \& Rittberger, 2008; Schuck \& De Vreese, 2006). Using survey-based studies, other research has demonstrated media effects on EU attitudes. For instance, De Vreese \& Boomgaarden (2006) have shown how the tone of news media affects support for further EU enlargement by connecting media content and survey data in two different countries (see also Azrout, van Spanje, \& De Vreese, 2012). Recent studies stemming from the $2009 \mathrm{EP}$ elections have also shown how exposure to news can affect both turnout (Schuck, Vliegenthart, \& de Vreese, 2016) and vote choice (van Spanje \& de Vreese, 2014).

The first paper on the theme 'media and voters' in this issue deals with the impact of news coverage on changes in EU attitudes. De Vreese, Azrout, and Moeller (2016) test how public evaluations of the performance of the European Union changed in the run up to the elections in response to news coverage. They investigate the role played by the news media in shaping public opinion about EU performance by linking citizens' evaluations across time collected in panel survey data to the news media content they were exposed to. They show that public opinion has changed towards the more negative, but also how exposure to media coverage can help improve citizens' evaluations of EU performance.

Meijers and Rauh (2016) study patterns of partisan mobilisation on EU issues in the news in France and the Netherlands. Comparing the 2014 EP elections to the 2009 elections, on aggregate they find no significant differences regarding party mobilisation on EU issues. Their main focus is, however, on the ways in which visible mobilisation efforts of challenger parties affect those of other parties in the news. Their analyses show that while mostly mainstream and especially incumbent parties publically mobilise on European issues during both campaigns, the mobilisation efforts from 'radical' parties became more visible during the 2014 elections. Furthermore, the visibility of Eurosceptic parties exhibits significant contagion effects on mainstream parties' visibility in the news. But the extent of these short-term effects was lower in the 2014 campaign than it was in 2009.

Turning to vote choice, Kleinnijenhuis and van Atteveldt (2016) show how the European elections in 2014 were the first to be held after a long period in which EU-related news was dominant in the media. Their paper asks how vote choice was influenced by campaigning on EU related issues. A news effects analysis based on a content analysis of Dutch newspapers and television, and on a panel survey among Dutch voters revealed that EU issues functioned as wedge issues: the more strongly parties were associated in the news with the euro crisis and the Ukraine crisis, the less they succeeded in getting voter support.

Collectively, the three papers show both change and continuity vis-à-vis extant research. The 2014 EP elections were different in the sense that they took place after a period of time in which the EU was much more visible on the media agenda than in any earlier election. However much of this coverage was devoted to the EU's international role (e.g., in relation to the Crimea issue) or the economic developments in the EU and its member states. These are not necessarily topics that the EP elections address. The 2014 EP elections 
were also different in the sense that they took place after a period of increasing politicization of EU politics. However, this increase did not per se improve the public debate about the EU and Europe. In terms of the effects of exposure to news content, the scoreboard, as seen from the EP, is mixed. On the one hand, exposure to information about the EU resulted in less negative evaluations of the performance of the EU. This is arguable good news for the EP as long as a sizeable share of EU citizens turns to mainstream news sources. However, it was also found that being associated with EU issues (albeit not all about the EP elections) was negatively associated with electoral success, that is to say, the EU is a topic on which parties can potentially lose votes.

\section{Theme 3: Electoral Behaviour}

The dominant paradigm in research on voting behaviour in EP elections is that these elections are secondorder national elections. In short, the theory holds that voters are largely unaware of European politics, that it is unclear what is at stake at these elections, that there are no clear issues on the basis of which people can choose between parties. In this situation, voters may either decide not to vote, or if they vote, to use their knowledge of national politics and national parties as an information shortcut. So, voters who turnout at these elections, use them mainly to express a preference for national parties. According to Van der Eijk, Franklin, and Marsh (1996), compared to national elections, at which executive power is at stake, EP elections display fewer signs of strategic voting ('voting with the head') and more signs of sincere voting ('voting with the heart') and protest voting ('voting with the boot'). As a consequence of these different motivations, EP elections display low turnout, a relatively poor performance of mainstream and especially governing parties, and more support for smaller radical parties (e.g., Reif \& Schmitt, 1980; Schmitt \& Thomassen, 1999; Thomassen, 2009; Van der Brug \& De Vreese, 2016; Van der Brug \& Van der Eijk, 2007; Van der Eijk \& Franklin, 1996).

Some studies in the last decade have questioned one of the main assumptions of the second-order perspective: that there are no clear issues at stake (e.g., Hobolt, Spoon, \& Tilley, 2009), arguing that the process of European unification has itself become more politicised and that this issue could play a particularly important role in European elections. However, while this could conceivably be the case, it is questionable whether this would make EP elections less second order. Steps towards further European integration are decided at the national level, so that European unification is in many ways also an issue in domestic politics. This argument has been made theoretically (e.g., Mair \& Thomassen, 2010; Schmitt \& Thomassen, 1999) and it has also been shown empirically that the issue of European integration plays a role in national elections (e.g., De Vries, 2009, 2010).

However, as we argued in the first section of this introductory paper, there were some elements of the 2014 EP elections, which had the potential to change its 'second-orderness'. As a result of the institution of Spitzenkandidaten, some executive power was now at stake, although it may not have been very clear to most voters. The austerity measures imposed on the Eurozone members that were rescued from bankruptcy, made visible how much sovereignty has been handed over by national states to the European level. Even if European elections offer little possibility to express policy preferences on these austerity measures-nor on other policies that are decided at the level of the EU-voters may become more aware of the importance of the EU and, hence, could be more motivated to participate in EU elections. The four contributions on these kinds of themes show, however, very little evidence that the EP elections of 2014 are less second order than previous ones.

To test the second order model, Kelbel, van Ingelgom and Verhaegen (2016) make use of the fact that the 2014 EP elections were held on the same day as regional elections in Belgium. As a consequence of the federalisation of Belgium, many important policies are decided at the level of the two regions Wallonia and Flanders, so that these regional elections can be considered to be (near) first order elections. The paper looks at motivations for split-ticket voting, to assess whether people employ different considerations when voting for representation at the different levels. Also, they compare 2014 and 2009, when EP elections also coincided with regional elections. The article shows that split-ticket voting cannot be explained by economic voting, European identity, nor by attitudes towards integration in 2014. The introduction of Spitzenkandidaten did enhance split-ticket voting for Flemish voters who could directly vote for the Flemish candidate Verhofstadt, while this did not increase split-ticket voting among voters who could only indirectly support the candidate (in Wallonia). This result thus suggests that the 2014 EP elections were still largely second order ones.

Boomgaarden, Johann and Kritzinger (2016) make use of panel survey data in Austria to study the motives to change one's party choice between a national and a European election. Looking first at aggregate level patterns in the switches, these are by and large in line with the second order framework. Citizens were less inclined to turnout at the EP election than in national elections, they switched away from government parties and smaller parties did relatively well. When looking at individuals' motivations for vote switching, they find that switches from government to opposition parties are largely driven by discontent with the national government. In line with Hobolt et al. (2009) they find Euroscepticism to be an important predictor of switches to anti-EU parties.

Okolikj and Quinlan (2016) employ the European 
Elections Studies (EES) data from 2009 and 2014 to assess economic voting in EP elections. Their study demonstrates that perceptions of the economy influenced voters in both election years. In 2009 this was an across the board effect, while in 2014 the effects of economic perceptions were conditioned by how much responsibility voters felt the national government had for the state of the economy. The study also reveals cross-country differences. In particular, the effects were stronger in the bailout countries compared to non-bailout countries. As the effects of economic perceptions are conditioned by perceptions of responsibility of the national government, these results clearly support the second order perspective on EP elections.

Schmitt and Toygür (2016) employ data from the EES 2014, as well as aggregate level data on election outcomes to test the second order model. As an alternative they test two hypotheses on whether consequences of the financial crisis explain the outcomes of the EP elections instead of the second order model. The authors analyse aggregate election results, both at the country level and at the party level and compare them with the results of the preceding first-order national election in each EU member country. All of the tests of the model, the bivariate as well as the multivariate ones are in line with the second order model.

\section{In Conclusion}

The 2014 EP elections were held under the slogan 'this time it's different'. The main idea was that, as a result of the introduction of the Spitzenkandidaten, executive power was at stake for the first time. Since there was more at stake, the elections would be 'different', meaning more first order in the perceived ranking of voters and parties. In this issue we posed the question whether this was true: 'How different were the EP elections of 2014?' Reviewing the eleven contributions in this issue, we can conclude that 2014 was not as different from previous elections as one might have expected given the different political and economic landscape and self-proclaimed relevance of the EP. Like in previous EP elections, turnout was low, and governing parties did not do well, while more radical Eurosceptic parties were rather successful. So, neither the introduction of Spitzenkandidaten, nor the increased politicisation around the EU, did much to change the second order nature of European elections.

One plausible reason for why the introduction of Spitzenkandidaten had little effect could be that only few voters were aware of the new element. Moreover, the role of these Spitzenkandidaten remained largely unclear during the campaigns. Especially if Junker would be up for re-election in 2019, this would generate a very different type of campaign dynamic and would conceivably generate greater media attention across Europe. This, in turn, could potentially make Eu- rope's citizens more aware of the candidates and their party political affiliations (Gattermann et al., 2016) and affect voter attitudes towards the EU or specific policy positions (see Maier et al., 2016), which might become decisive for their electoral behaviour.

In addition to the Spitzenkandidaten, the political context of the 2019 EP elections will also matter. In the coming years, the EU is facing a number of big challenges, such as the refugee and ongoing sovereign debt crises, but also the possibility of a Brexit. These challenges will make EU affairs more salient in the public eye. Yet, the increased salience of 'Europe' will not by itself make EP elections less second order. That will depend on whether there is something at stake, such as the re-election of the Commission President, and whether voters are aware of what is at stake.

\section{Conflict of Interests}

The authors declare no conflict of interests.

\section{References}

Azrout, R., van Spanje, J. H. P., \& De Vreese, C. H. (2012). When news matters: Media effects on public support for EU enlargement in 21 countries. Journal of Common Market Studies, 50(5), 691-708.

Boomgaarden, H. G., Johann, D., \& Kritzinger, S. (2016). Voting at national versus European Elections: An individual level test of the second order paradigm for the 2014 European Parliament Elections. Politics and Governance, 4(1), 130-144.

De Vreese, C. H., Azrout, R., \& Möller, J. (2016). Cross road elections: Change in EU Performance evaluations during the European Parliament Elections 2014. Politics and Governance, 4(1), 69-82.

De Vreese, C. H., \& Boomgaarden, H. G. (2003). Valenced news frames and public support for the EU. Communications, 28(4), 361-381.

De Vreese, C. H., \& Boomgaarden, H. G. (2006). Media effects on public opinion about the enlargement of the European Union. Journal of Common Market Studies, 44(2), 419-436.

De Vreese, C. H., \& Boomgaarden, H. G. (2016). Effects of news media coverage on public support for European integration. In W. van der Brug \& C. H. De Vreese (Eds.), (Un)intended consequences of European Parliament elections (pp. 237-254). Oxford: Oxford University Press.

De Vreese, C. H., Boomgaarden, H. G., \& Semetko, H. A. (2011). (In)direct framing effects: The effects of news media framing on public support for Turkish membership in the European Union. Communication Research, 38(2), 179-205.

De Vries, C. E. (2009). The impact of EU referenda on national electoral politics: The Dutch case. West European Politics, 32(1), 142-171. 
De Vries, C. E. (2010). EU issue voting: Asset or liability? How European integration affects parties' electoral fortunes. European Union Politics, 11(1), 89-117.

Føllesdal, A., \& Hix, S. (2006). Why there is a democratic deficit in the EU: A response to Majone and Moravcsik. Journal of Common Market Studies, 44(3), 533562.

Franklin, M. N. (2014). Why vote at an election with no apparent purpose? Voter turnout at elections to the European Parliament. European Policy Analysis, 2014(4), 1-11.

Gattermann, K., De Vreese, C. H., \& van der Brug, W. (2016). Evaluations of the Spitzenkandidaten: The role of information and news exposure in citizens' preference formation. Politics and Governance, 4(1), 37-54.

Hix, S. (2002). Constitutional agenda-setting through discretion in rule interpretation: Why the European Parliament won at Amsterdam. British Journal of Political Science, 32(2), 259-280.

Hix, S. (2008). What's wrong with the European Union and how to fix it. London: Polity.

Hobolt, S. B. (2014). A vote for the President? The role of Spitzenkandidaten in the 2014 European Parliament elections. Journal of European Public Policy, 21(10), 1528-1540.

Hobolt, S. B., \& Spoon, J. -J. (2012). Motivating the European voter: Parties, issues and campaigns in European Parliament elections. European Journal of Political Research, 51(6), 701-727.

Hobolt, S. B., Spoon, J. J., \& Tilley, J. (2009). A vote against Europe? Explaining defection at the 1999 and 2004 European Parliament elections. British Journal of Political Science, 39(1), 93-115.

Hobolt, S. B., \& Tilley, J. (2014). Blaming Europe? Responsibility without accountability in the European Union. Oxford: Oxford University Press.

Kelbel, C., van Ingelgom, V., \& Verhaegen, S. (2016). Looking for the European voter: Split-ticket voting in the Belgian Regional and European Elections of 2009 and 2014. Politics and Governance, 4(1), 116-129.

Kleinnijenhuis, J., \& van Atteveldt, W. (2016). The impact of the explosion of EU News on voter choice in the 2014 EU Elections. Politics and Governance, 4(1), 104-115.

Maier, J., \& Rittberger, B. (2008). Shifting Europe's boudnaries. Mass media, public opinion and the enlargement of the EU. European Union Politics, 9(2), 243-267.

Maier, J., Rittberger, B., \& Faas, T. (2016). Debating Europe: Effects of the "Eurovision Debate" on EU attitudes of young German voters and the moderating role played by political involvement. Politics and Governance, 4(1), 55-68.

Mair, P., \& Thomassen, J. (2010). Political representation and government in the European Union. Journal of European Public Policy, 17(1), 20-35.

Meijers, M., \& Rauh, C. (2016). Has Eurosceptic mobiliza- tion become more contagious? Comparing the 2009 and 2014 EP Election campaigns in The Netherlands and France. Politics and Governance, 4(1), 83-103.

Okolikj, M., \& Quinlan, S. (2016). Context matters: Economic voting in the 2009 and 2014 European Parliament Elections. Politics and Governance, 4(1), 145-166

Put, G. J., Van Hecke, S., Cunningham, C., \& Wolfs, W. (2016). The choice of Spitzenkandidaten: A comparative analysis of the Europarties' selection procedures. Politics and Governance, 4(1), 9-22.

Reif, K., \& Schmitt, H. (1980). Nine second order national elections: A conceptual framework for the analysis of European election results. European Journal of Political Research, 8(1), 3-44.

Schmitt, H., \& Thomassen, J. (Eds.). (1999). Political representation and legitimacy in the European Union. Oxford: Oxford University Press.

Schmitt, H., \& Toygür, I. (2016). European Parliament Elections of May 2014: Driven by national politics or EU policy making? Politics and Governance, 4(1), 176-181.

Schuck, A. R. T., \& De Vreese, C. H. (2006). Between risk and opportunity: News framing and its effects on public support for EU enlargement. European Journal of Communication, 21(1), 5-32.

Schuck, A. R. T., Vliegenthart, R., \& de Vreese, C. H. (2016). Who's afraid of conflict? The mobilizing effect of conflict framing in campaign news. British Journal of Political Science, 46(1), 177-194.

Schulze, H. (2016). The Spitzenkandidaten in the European Parliament Election campaign coverage 2014 in Germany, France, and the United Kingdom. Politics and Governance, 4(1), 23-36.

Thomassen, J. (Ed.). (2009). The legitimacy of the European Union after enlargement. Oxford: Oxford University Press.

Van der Brug, W., \& De Vreese, C. H. (Eds.). (2016). (Un)intended consequences of European Parliamentary elections. Oxford: Oxford University Press.

Van der Brug, W., \& Van der Eijk, C. (Eds.). (2007). European elections and domestic politics: Lessons from the past and scenarios for the future. Notre Dame, IN: University of Notre Dame Press.

Van der Eijk, C., \& Franklin, M. N. (Eds.). (1996). Choosing Europe? The European electorate and national politics in the face of the Union. Ann Arbor: University of Michigan Press.

Van der Eijk, C., Franklin, M., \& Marsh, M. (1996). What voters teach us about Europe-wide Elections; What Europe-wide elections teach us about voters. Electoral Studies, 15(2), 149-166.

Van Spanje, J. H. P., \& de Vreese, C. H. (2014). Europhile media and Eurosceptic voting: Effects of news media coverage on Eurosceptic voting in the 2009 European Parliamentary elections. Political Communication, 31(2), 325-354. 


\section{About the Authors}

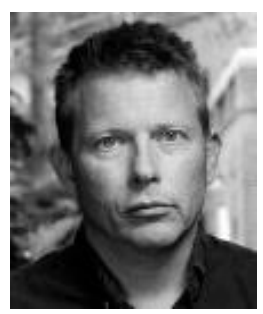

Prof. Dr. Wouter van der Brug

Wouter van der Brug is Professor and Chair of Political Science at the University of Amsterdam. His research interests focus on comparative research in collective political behaviour, in particular electoral behaviour, right-wing populism, political trust and support and political parties. He publishes regularly in various international Political Science journals. His most recent (co-authored/co-edited) books are The Politicisation of Migration (2015, Routledge) and (Un)intended Consequences of European Parliament Elections (2016, Oxford UP).

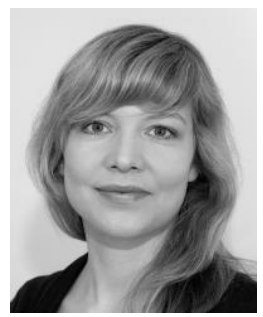

\section{Dr. Katjana Gattermann}

Katjana Gattermann is assistant professor of political communication and journalism at AScoR and also affiliated with ACCESS EUROPE at the University of Amsterdam. She is founding director of the Erasmus Academic Network on Parliamentary Democracy in Europe (PADEMIA). Her research interests comprise political communication, political behaviour, public opinion and legislative behaviour in the EU. Her work has appeared in journals such as the European Journal of Political Research, European Union Politics, and West European Politics.

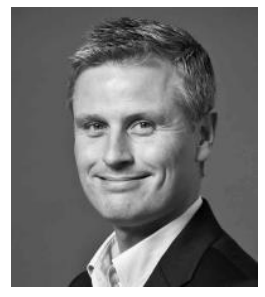

\section{Prof. Dr. Claes de Vreese}

Claes de Vreese is Professor and Chair of Political Communication at ASCoR at the University of Amsterdam. He is the founding Director of Center for Politics and Communication (www.polcomm.org). His research interests focus on political journalism, media effects, public opinion and electoral behaviour. His most recent (co-authored) books are Political Journalism in Comparative Perspective (Cambridge UP) and (Un)intended Consequences of European Parliament Elections (Oxford UP). 